\title{
THE ROLE OF WAGE AND SKILL DIFFERENCES IN
}

US-GERMAN EMPLOYMENT DIFFERENCES

\author{
Richard B. Freeman \\ Ronald Schettkat \\ Working Paper 7474 \\ http://www.nber.org/papers/w7474 \\ NATIONAL BUREAU OF ECONOMIC RESEARCH \\ 1050 Massachusetts Avenue \\ Cambridge, MA 02138 \\ January 2000
}

The views expressed herein are those of the authors and not necessarily those of the National Bureau of Economic Research.

(C) 2000 by Richard B. Freeman and Ronald Schettkat. All rights reserved. Short sections of text, not to exceed two paragraphs, may be quoted without explicit permission provided that full credit, including $\mathbb{C}$ notice, is given to the source. 
The Role of Wage and Skill Differences in US-German Employment Differences

Richard B. Freeman and Ronald Schettkat

NBER Working Paper No. 7474

January 2000

JEL No. E24, J23, J3

\section{ABSTRACT}

Greater job creation in the US than in Germany has often been related to greater wage dispersion coupled with less regulated labour and product markets in the US. Based on the Comparative German American Structural Database and the International Adult Literacy Survey we find that employment of skilled to unskilled labour is unrelated to differences in skill premium but that changes in relative employment are related to changes in relative wages raising the possibility of some substitution behavior. Still, the differing dispersion of wages is not a major contributor to differences in employment rates. The jobs problem in Germany is one of a general lack in demand for labor.

Richard B. Freeman

NBER

1050 Massachusetts Avenue

Cambridge, MA 02138

freeman@nber.org
Prof. Dr. Ronald Schettkat

Department of Economics and Policy Studies

Utrecht University

PO Box 80.140

NL-3508 TC Utrecht

The Netherlands

R.Schettkat@fss.uu.nl 
In the 1960s the employment-to-population ratio was about 7 points higher in Germany than in the US and the unemployment rate was lower. ${ }^{1}$ In 1997 the German employment to population rate was 10 points lower than the US employment to population rate ${ }^{2}$ and the unemployment rate exceeded the U S rate. W hy has the U S labour market been so much more succesfful in generating jobs than German or other European U nion labour markets?

The most popular explanations for greater job creation in the US than in Germany is that it is due to the great dispersion of wages in the US, particularly at the bottom of the earnings distribution, has induced firms to employ many less skilled workers coupled with less regulations governing the labour market and the product market. W hile popular, these explanations turn out to be difficult to prove empirically. They have been criticized for ignoring the fact that the distribution of skills in the EU and Germany differs markedly from that in the US (N ickell and Bell).

In this study we combine information from a new data set, the Comparable German A merican Sectoral (CGAS) D atabase with data from the OECD's A dult Literacy Survey to examine the relation between wages, skills and employment in the two countries. The CGA S classifies workers in the two countries into comparable detailed occupation (about 95) and industry (about 65) classifications for the period 1970 to 1995 (for more details see Freeman/ Schettkat 1998). The underlying sources of the data for the CGAS database are the US Census of Population, the Current Population Survey,

${ }^{1} \mathrm{OECD}, \mathrm{H}$ istorical Statistics, Diskettes.

${ }^{2} \mathrm{OECD}$, Employment O utlook, 1998, table B, gives a rate for Germany of 63.5 and a rate for the US of 73.5 . 
the German M ikrozensus and German social security data (Beschaeftigtenstatistik). Combining these data files provides us with a detailed database, which allows, for example, for the detailed analysis of employment growth differentials by education and industry, occupation, age, etc. It includes wages, skills, age, sex, and nationality (theoretically the data allows for differentiation of about 1.2 million cells per year). The A dult Literacy Survey is a multi-country comparative study of adult literacy focused on the ability of adults to understand and use printed information through reading, writing, and numeracy, in their workplace and daily life. It is the first major international study focused on the literacy skills that workers have and use at workplace, and thus a valuable improvement or complement to analysis of skills based on educational attainment. It includes data on employment, unemployment, income, and diverse other socio-economic variables. Germany and the US were two of the countries in the initial seven-country study.

The paper has three parts. Section 1 reviews the evidence on US-German differences in employment and unemployment and in the structure of earnings. Section 2 contrasts the level of skill of German and A merican workers, which complicates comparisons of wage differences between the countries. Section 3 assesses the hypothesis that the growth of a U S-German employment difference is due, in part, to the divergent pattern of change in the earnings distributions and estimates the extent to which Germany might increase its employment rate or lower its unemployment rate if it reduced wages in the bottom part of the income distribution toward US wage levels.

We find that:

1. Employment rates differ more between the US and Germany than unemployment rates and differ by skill levels as well as overall.

2. German and US relative pay by level of skill was similar in 1970 but diverged in the 1980 s, 
when low skilled A mericans fell in the earnings distribution and low skilled Germans rose.

3. The German work force is more skilled than the US work force, with the least skilled German workers much closer to the national average than the least skilled US workers. This implies that measured in "effective" skill units, German and A merican wage distributions differ less in the bottom percentiles than at first appears to be the case.

4. The employment of skilled to unskilled labour within industries is unrelated to country differences in skill premium, which argues against any differential wage interpretation of US-German employment patterns. However, changes in relative wages are related to changes in relative employment and explain over half of the changed difference in relative employment.

5. The differing dispersion of wages between the US and Germany is not a major contributor to differences in employment rates. U sing our biggest estimate of the effect of skill premium on relative employment, we estimate that the German employment rate would rise by no more than 2 or so percentage points. If Germany reduced the unemployment to less skilled workers to US levels, its unemployment rate would fall by just 0.2 percent points.

In short, the jobs problem in Germany is not primarily one of relative labor demand but of demand for labor in general.

\section{Employment and U nemployment Patterns}

Table 1 contrasts aggregate economic outcomes and labor market trends in Germany and the US between the 1960s and 1990s. In virtually all periods, Germany has had faster growth in GDP per capita, GDP per employee, and real wages than the US, due undoubtedly to economic catch-up. In terms of the distribution of output, the share of profits in business sector output in Germany and 
in the US are quite similar. By these measures of economic performance, Germany does better or as well as the US. The only area in which Germany does more poorly is in terms of employment creation. It is these difference that has attracted international attention and is the focus of this paper.

There are three ways to measure US-German differences in the area of employment performance. M any analysts compare rates of unemployment, but these rates differ for reasons of definition as well as "real" behaviour. U sing the US Bureau of Labor Statistics's transformation of German rates to US concepts, Germany has lower unemployment than the US through the mid 1990s, but using national definitions, the German rate is higher even in the 1980s. By 1998, however, as the US enjoyed its longest peacetime boom, even the BLS rates show lower joblessness in the US than in Germany.

The second most commonly used measure is the ratio of employment to adult population. Here, US employment rates have risen substantially relative to German rates. O ne element of this is that employment has grown much more rapidly in the services sector in the US. A nother element is that women have had a more rapid growth of employment in the US. Yet another factor in the differential employment pattern is that older men retire more rapidly in Germany. A s a result of different labor participation behavior, even if Germany reduced its unemployment rate in 1997 to US levels, there would still remain an employment-population difference.

A third measure of labour utilization is hours worked per adult in the population, working hours in Germany have declined fairly steadily since 1960 while working hours in the US stopped falling after 1979. Germans have longer vacations and work fewer hours per week than A mericans. A s a result the biggest US-German gap is in working hours per adult -- the multiplicand of hours worked per employee times employees per adult. 


\section{dispersion of pay and relative wages}

Table 1 records one widely used measure of the dispersion of pay -- the ratio of earnings of the 90th percentile to the earnings of the 10th percentile separately for men and women, and for the two genders taken together. By all of the measures the dispersion of wages is considerably lower in Germany than in the US. M ore important, dispersion in Germany moves in the opposite direction to that in the US: it drops while dispersion in the US rises. It is these differences in level and trend in inequality that many analysts have seized on as offering a potential explanation for better job creation in the US (Siebert 1997:45). Germany, some argue, does not allow for sufficient downward wage flexibility for low paid workers, instead increasing relative pay of those workers which causes their employment to fall and unemployment to rise. By contrast, the US creates jobs for the less skilled by reducing the cost of this labour.

Figure 1 uses data from the CGA S that confirms the fact that dispersion of pay is markedly lower in Germany than in the US, and that this differential remains after accounting for differences in skill. It records two standard deviations in the log of wages for the two countries in 1989: a basic standard deviation "uncontrolled" for differing characteristics of workers within the cells for which the data set has observations. ${ }^{3}$ This is comparable to the OECD measures of dispersion in the table 1. By this metric, the dispersion in the US is some 0.12 log points higher than in Germany. The figure also records standard deviations of residual earnings from a simple log linear regression of wages on dummy variables for skill groups. The residual standard deviations relate to differences in earnings

3 The original source for wages in the CGAS is the Beschäftigtenstatistik, which is cen sored at the high wage end because of the ceiling for social security contributions ( see M öller for a discussion). Therefore, we underestimate wage dispersion in Germany. Whether this leads to overestimation of German-US difference in wage dispersion is not clear because fringe benefits (not measured as wages) are more important among high-income A mericans. 
within skill categories. They are also about 0.12 log points higher in the US than in Germany. M ore detailed calculations that control for additional covariates show a similar story: within group dispersion of pay is much higher in the US than in Germany (Freeman and Schettkat, 1999).

Table 2 turns from overall levels of dispersion to relative wages of specific skill groups. Columns 1 and 2 use the CGA S data to contrast the relative wages of four groups of workers divided by skill class from low skill (I) to high skill (IV) based on education in Germany and the US. The wage of the highest skill group in a country year is given a value 100 and the wages of other groups are reported relative to the highest level. The underlying data permit alternative aggregations of within country educational groups for comparability between the two countries. We chose an aggregation that puts US high school graduates who receive no further education in the lowest skill category, as described in section II. A Iternative aggregations will produce somewhat different relative wages and employment shares but will not alter the basic fact shown in the table. This is that relative wages moved differently between the countries so that the relative pay of the less skilled ends up higher in Germany than in the US.

In 1970 there is little difference in the relative wages paid to the different skill groups. This is not inconsistent with the US having greater overall dispersion of wages because much of US wage dispersion occurs within educational groups. From 1970 to 1989, however, the US relative wages of the lowest skill group and of the second lowest skill group declined whereas the reverse trends occurred in Germany. ${ }^{4}$ At the same the time the employment shares of the lowest skill group dropped

4 Due to a change in the treatment of one-time payments in social security contributions there is a structural break in the wage series in 1983, which does not affect measured wages of the lower income groups but wages of the middle income groups ( $M$ öller). The break in the wage series may lead to an underestimation of the true rise in the $\mathrm{W} s / \mathrm{W} u$ ratio (W $s=$ wages of skilled workers, $\mathrm{W} u=$ wages of unskilled workers) and thus to an overestimation of the elasticity of substitution (see below). 
to roughly half of its 1970 s level in Germany. The decline of this share in the US was smaller. The lowest skill group lost only about a quarter of the 1970 share and therefore had only half as rapid a decline as in Germany. These differing changes in relative employment and relative wages are consistent with the notion that they are driven by differing changes in relative wages operating on demand curves -- a fact that we exploit later.

The International A dult Literacy Survey sponsored by the OECD provides an alternative source of data on relative wages by skill groups. The A dult Literacy Survey also distinguishes four comparable education groups, but with a somewhat different grouping than we used in the CGA S. Still, the data summarized in Table 3 give a similar result. This table shows that the OECD's estimated rates of return to educational attainment are higher in the US than in Germany, with the bulk of differences found between the least educated, those with lower secondary schooling and more skilled workers. Separate within country regressions of In earnings on years of schooling in the CGA S and OECD data sets show that a year of schooling has a higher effect on earnings in the US than in Germany.

\section{The Skill Issue}

W hen workers with nominally the same levels of educational qualification or in the same percentiles of the earnings distribution have markedly different wages between countries, those wage differences become a potential cause of differences in employment. Indeed, many analysts who have compared Germany and the US take this as a point of departure. But as Nickell and Bell have pointed out, there seem to be substantial skill differences among nominally similar workers between Germany (other EU countries) and the US that makes such contrasts less reliable than might first appear to be the case. If German less skilled workers are more skilled than A merican less skilled 
workers while German skilled workers are similar to A merican skilled workers, at least some of the relatively higher pay of less skilled Germans and of the narrow dispersion of wages in Germany would represent a return to skill. M easured in "efficiency units", the German wage distribution would be more dispersed than nominal wages indicate.

Thus the question: how different are the skill distributions of Germany and the US?

This is not an easy question to answer because available measures of labor skill are primitive, based largely on educational attainment rather than workplace competencies, and because the US and German educational systems differ considerably. Years of education do not provide a particularly good measure of differences in schooling because German schooling involves apprenticeships, which differ greatly from formal schooling in the US. If one compares formal schooling it is necessary to go beyond years of schooling and establish some form of equivalence between German and US educational attainment. W e have developed such equivalence classes for the CGA S (Figure 2). M ost analysts will probably agree with our setting A mericans with master's degrees or more and Germans with university degrees as the highest comparable skill group; and setting U .S. bachelor's graduates and Germans with Fachhochschule, A rbitur + Fachhochschule as the second highest group. By these equivalence scales, Germans have a somewhat higher proportion of workers in the Skill category IV while A mericans have a much higher proportion in Skill Category III (see Table 2). Taking these two groups together, the US has relatively more highly skilled workers than Germany.

In the least skilled group we have put Germans with no certificate and A mericans who have not graduated high school. The difficult question is how to treat $\mathrm{G}$ ermans with some completed form of apprenticeship and A mericans with high school degrees or with some post-secondary education but no bachelor's degree. A pprenticeship gives Germans more skills than A merican high school 
graduates who obtain no additional training, but grouping A merican high school graduates with dropouts in the lowest category is excessive: dropouts are considered as failures in the US while high school graduates have successfully met their required schooling. Still, we have placed A merican high school graduates who obtain no additional education in the low skill category, Skill Level I. The rationale for this decision can be seen in the scores on the A dult Literacy Survey given in table 4. The average literacy scores (the average of prose, document, and quantitative skills) of A mericans with just a high school degree falls slightly below those of Germans with less than upper secondary education, so that by this measure these A mericans are more comparable to Germans in Skill Level I than in Skill Level II. ${ }^{5}$ By contrast, the mean score of Germans with less than upper secondary education (roughly equal to our skill group I) is roughly equal to the overall mean score for the US. The US-German difference at the low level of the education scale is also reflected in the proportion of those who have not completed upper secondary education but who nevertheless score at levels 3 and $4 / 5$ on the document scale. Fifty percent of those who have not completed upper secondary education are in this group compared to only 17.1\% A mericans (OECD 1997, Literacy Skills 153). This difference is especially marked in blue-collar occupations. A mong machine operators and skilled craft workers the difference in the share of workers who achieve literacy levels of 3 and more is substantial: $55 \%$ of the Germans in these occupations achieve this level compared to only $32 \%$ of the A mericans in similar occupations. A gain, the major difference is in literacy level 1, where are about $33 \%$ of the A mericans in these occupations but only about $8 \%$ of the Germans. (OECD 1997,

\footnotetext{
${ }^{5}$ Due to coding problems, the scores for G ermans classified as 'less than upper secondary education' may be
} 


\section{Literacy Skills 153)}

Categorizing US high school graduates in Skill Category I, the vast bulk of A merican workers in 1969 are in the low skill category while over half are in that category in 1989. The reader who finds this treatment of US high school graduates as excessive can shift some (moderate) proportion of the group to the second category without changing the two substantive results that we draw from the tables: that the German work force is on average more skilled than the A merican work force, with a fatter "middle" of the skill distribution than in the US.

A nother way to contrast the German and US skill distributions is to put educational attainment aside and simply look at scores on the OECD's literacy and numeracy test. Table 5 compares the percentile distributions of scores for the two countries. The mean level for Germany is moderately higher than for the US. The difference in means reflects the fact that while the US has modestly higher scores at the upper percentiles, Germany has markedly higher scores in the lower percentiles, particularly at the very bottom of the test score distribution. Table 6 demonstrates the same fact in another way. It shows the distribution of A mericans and Germans among the literacy/numeracy skill categories that the OECD uses. There are proportionately fewer Germans than A mericans in the lowest skill category and modestly fewer Germans than A mericans in the highest skill category.

Finally, consider the proportion of German and A merican workers who report that they engage in a variety of reading, writing, and numerical tasks regularly at their workplace. Table 7 
shows that for the vast bulk of activities, Germans report engaging in the literacy/writing tasks to a greater extent than A mericans. By contrast, A mericans report that they do more numeracy tasks than Germans. Disaggregated by occupation, the differences in tasks are modest among professionals/managers but are substantial among machinery operators, service workers, and workers in other occupations where most workers lack a university degree (OECD 1997). Although these measures do not fully reflect workplace productivity -- a diligent pleasant employee may do more in trade or services than someone who fills out forms -- they are consistent with our classification of groups in the CGA S and with the results of the A dult Literacy Survey.

\section{The Effect of Skills on W ages and Employment}

There are two ways in which the greater level of skill of Germans than A mericans at the low -end of the skill distribution affect U S-German comparisons. First, it implies that comparisons of the dispersion of wages and relative wages based on measured wages exaggerate US-German differences in the distribution of earnings in the more appropriate "efficiency units". Part of the reason that the German wage distribution is more concentrated than the A merican distribution is simply that Germans are more alike in terms of their labor skills. Second, it raises questions about drawing any inferences for low skill German workers from the experience of low skill A merican workers. By some measures the least skilled or educated Germans look more like average A merican workers than they look like low skilled A mericans. This suggests that the right contrast is between Germans in the bottom decile of the German earnings distribution and A mericans a decile or more higher in the US earnings distribution.

To what extent do skill differences explain the lower dispersion of wages and return to skills 
found in Germany than in the US?

In its analysis of the effect of schooling the OECD examined the joint effect of literacy and educational attainment on incomes and found that literacy and education had bigger effects on income in the US than in Germany. The coefficients on education were 0.244 for Germany and 0.302 for the U.S. -- a substantial difference given that the literacy score was held fixed. The coefficients on literacy differed even more: 0.296 for the U.S. versus .189 for Germany. The implication is that, while controlling for literacy may reduce the differential effect of schooling on incomes, the US still has a higher premium; and that literacy pays off more in the US than in Germany. O ur contrasts of the standard deviation of In earnings between the US and Germany in figure 1 tell a similar story for the effect of schooling on the overall dispersion of earnings. Perhaps a measure of literacy would narrow US-German dispersion more in the CGAS but there is nothing in the $O E C D$ results to suggest that this effect would be great.

That G ermans with limited education have literacy skills close to those of G ermans who have completed upper secondary school has implications for comparisons of relative employment and relative wages between Germany and the US. It suggests that it will be difficult to assess substitution between German workers in Skill C ategory I and II because these workers are in fact relatively close substitutes. Estimates of substitution between low skill and other workers that link relative employment of workers in low skill occupations or with low education should give higher elasticities in the US than in Germany. Given comparable demand-side shocks against low skilled workers, US workers with low skills would require a greater wage reductions to maintain employment than German workers with "low" skills, because in fact the Germans are not that different from other workers, whereas the low skill A mericans are very different. 
To what extent does the greater skill of lower skilled Germans imply that reductions in their relative pay would not create jobs comparable to those that lower skilled A mericans hold? A re there enough low skilled Germans available to work in low level M cjobs?

Table 8 contains data from the OECD literacy file that answers this question. In both Germany and the US the less skilled have higher rates of unemployment than the more skilled. In Germany those with a literacy proficiency at levels $1 / 2$ have an unemployment rate of $16.5 \%$. In the US those with a literacy proficiency at levels $1 / 2$ have an unemployment rate of $7.1 \%$ in the US (1994-1995). A mong those with a higher level of literacy proficiency (levels 3 and 4/5) the unemployment rate is roughly half as high (7.2\% in Germany and 3.4\% in the US, see O ECD 1997). As $\mathrm{N}$ ickell and Bell have pointed out, the ratio of unemployment rates in high unemployment Europe is similar to the ratio of unemployment rates in the low unemployment US. But there is a sufficient proportion of unemployed low skilled Germans to reject the claim that Germany lacks low level service sector jobs because its labor force is too skilled to take such jobs. There are also, however, a substantial number of Germans with low literacy who are out of the labor force. Table 8 shows that Germany has lower labor force participation rates at all levels than the US and that in both countries participation is higher at higher levels of literacy proficiency. The difference in labor force participation is 14.0 percentage points at level $1 / 2$ and 13.0 percentage points at level 3 or more. Thus it is not the case that in Germany the less skilled are more than proportionally excluded from the labor market. Labor force participation in Germany is lower across the literacy levels.

In terms of substitution on the demand side of the market, what matters is not relative unemployment or labor participation rates but employment. Since employment rates are equal to labor participation rates multiplied by 1-unemployment rates, the differences in unemployment and 
participation translate into relatively lower employment of workers with low literacy in Germany than in the US. The employment to population ratio of $\mathrm{G}$ ermans with levels $1 / 2$ of literacy proficiency is $73 \%$ that of Germans with levels 3,4/5 of literacy proficiency, whereas the employment to population ratio of $A$ mericans with levels $1 / 2$ of literacy proficiency is $84 \%$ that of $A$ mericans with $3,4 / 5$ of literacy proficiency. It is this statistic rather than the proportionality of unemployment rates that is the key for analyzing the possible effect of relative earnings on the German and US labour markets. A fter all, relative wages are supposed to affect relative employment rates along the demand curve. The effects on relative unemployment rates is more indirect, depending in part on labor participation responses and on the actual level of unemployment. ${ }^{6}$

In sum, our examination of the effects of skill on wages and employment modifies but does not overturn the two basic facts that have led some analysts to argue that at least some of the greater job creation in the US than in Germany is due to the compression of wages at the bottom of the German wage distribution. A djusted for skill, the German distribution of wages remains more compressed than the A merican distribution, and disproportionately fewer low skill Germans than low skill A mericans are employed, though there is little difference in the ratio of unskilled to skilled unemployment rates

\footnotetext{
${ }^{6}$ By definition the employment to population rate (E/P) equals the labor participation rate (LF/P) times ( $1-U N E$ ), where $U N E$ is the unemployment rate. If $L F / P$ is fixed, and $U N E$ is relatively small, In E/P = -UNE so that percentage changes in employment rates translate into absolute
} 
between the countries.

\section{relative wages and employment}

How large an elasticity of substitution between skilled and unskilled labor is needed for relative wage flexibility to explain the differing pattern of employment creation by level of skill between Germany and the US?

To answer this question, we return to the CGA S data in table 2. Because we are concerned with the least skilled workers, we define skill level I as unskilled and combine skill levels II, III, and IV to form a composite skilled group. Then, the employment data in the table show that between 1970 and 1989 the ratio of unskilled to skilled workers fell by - 0.38 In points in the US compared to -0.60 In points in Germany for a differential change of -0.22 In points. Similarly, in the US the wage of workers in skill group I relative to all other workers fell by -0.031 while in Germany it rose by 0.057 In points, giving a differential change of 0.088 . For a differential wage change of .088 to explain a differential employment change of -0.22 requires an elasticity of substitution of 2.5 . This is a high elasticity of substitution but not one that is out of the range of at least some econometric estimates (Bound/ Johnson have an elasticity of 1.7 for the US, Katz and M urphy of 1.4 and Beissinger/M öller have a value of 1.8 for men and 3.3 for women in Germany, Fitzenberger/ Franz find elasticities of substitution between .4 and 2.5 depending on industries, Steiner and $W$ agner find one of .3 for manufacturing industries).

W hat magnitude of an elasticity do we find in the CGA S?

changes in unemployment rates. 
There are several ways to estimate the elasticity of substitution between unskilled and skilled workers in the data set. M imicking the aggregate comparison above, we first compare the relative employment of unskilled workers in Germany and in the $U S$ to their respective relative wages among industries. The assumption is that each industry faces a separate relative wage of the unskilled workers in the two countries and determines relative employment in response to these relative wages. Lines 1 and 2 in table 9 show the result of this exercise for 1970 and 1989, respectively. There is little evidence that sectors in Germany with a higher relative wage for unskilled workers than the same sector in the US hire relatively fewer unskilled workers. A $\mathrm{n}$ alternative comparison is to look at changes over time in the two countries separately. The assumption is that each industry faces a distinct change in relative wages and responds by adjusting relative employment. Lines 3 and 4 of table 9 show that this yields very different results for the US and Germany. Sectors in the US show a fairly sizeable elasticity of substitution while those in Germany show a modest elasticity relation that is insignificantly different from zero. Finally, we can combine the cross country and over time analyzes into a difference in difference model in which we relate the German-US difference in the change in In relative employment of unskilled workers to the German-US difference in the change in In relative wages (line 5). The assumption here is that industries in both countries operate along the same isoquant and that changes in relative wages explain changes in relative employment. In this case, we obtain a sizeable 1.5 elasticity of substitution, which suggests that as much as $60 \%$ of the USGerman difference in changes in relative employment are associated with differences in changes in relative wages. If this result was based more or less equally on German and US within country patterns, we would regard it as a strong one, but as the separate country regressions show, the 
difference in difference estimate comes largely from the negative relation between changes in relative employment and relative wages in the US. W e have given the results of all of the comparisons in table 9 to make it clear that the diff in diff estimate should be viewed as a maximal estimate of the elasticity, based largely on US behaviour. Even in the US, however, there has been no increase in employment to population rates for unskilled labor but rather a slower substitution of unskilled by skilled labor in industries than in Germany. W hether higher wage flexibility for low wage workers can actually raise the unskilled labor to skilled labor ratio under modern technological conditions remains an open question.

We show next that even with this estimate only a modest proportion of US-German employment or unemployment differences can be attributed to the compression of wages at the bottom of the German wage distribution.

\section{from relative to aggregate employment and unemployment}

A ssume that in fact there is a relatively high elasticity between more skilled and less skilled workers in Germany as in our difference in difference model. If the relative pay of less skilled Germans dropped to US levels, how much might the ratio of employment to population rise in Germany and how much might unemployment rates fall?

The most that one would expect German low skill employment to rise would be to comparable US employment levels. Since employment rates are generally higher in the US we use as reference the employment rates of the low skilled workers relative to that of the skilled workers (hypothetical rates I in Table 10). Raising the employment of less skilled workers to US levels would presumably reduce employment of the skilled workers if there is some elasticity of substitution between the groups. W e neglect this effect and discuss only extreme scenarios in which employment of skilled 
workers is unaffected. If the employment rate of less skilled German would be raised to relative US levels the employment rate of low skilled Germans would rise by nearly 10 percentage points from 44.7 percent to 54.4 percent -- creating an additional jobs for 944,000 low skilled workers. This is higher than the labor force participation rate of this group in Germany. H owever, under this extreme assumptions the overall employment rate would rise by just 2.2 percentage points. The low skilled simply do not make up a sufficiently large proportion of the German work force to bring German employment rates to US levels. The unrealism of this assumption is shown in the simulated unemployment rate for low skill workers, which would fall to zero (the increase in employment requires an increase in labor participation), bringing the aggregate unemployment down by over 2 percentage points.

A ssume instead that we lower the relative wage of the less skilled Germans by $10 \%$ and apply it to our maximal 1.5 elasticity of substitution to see how many low skill jobs might be created. In this case we would get an employment rate of 51.4 percent with an additional employment of 653,000 and a fall in unemployment down to virtually zero (Table 10 , scenario II). A gain under the assumption that skilled employment is unaffected, the aggregate unemployment rate drops by 2.2 points and the employment raises by 1.5 points.

Scenarios that postulate that reductions in the wages of the less skilled Germans would produce lower rates of joblessness for unskilled Germans than for unskilled A mericans are highly unrealistic. Consider a more realistic scenario in which reductions in wages/increased flexibility reduce the unemployment rate of the less skilled Germans relative to that of skilled Germans to the unemployment rate of unskilled A mericans relative to that of skilled A mericans. This applies an unemployment rate of the less skilled in Germany of $11.7 \%$ ( $T$ able 10 , scenario III). It requires an 
additional employment of 75,000 unskilled workers. The group-specific employment rate would rise by 0.8 points and the aggregate employment rate would rise by 0.2 points. These scenarios assume that a drop in the relative wage of less skilled labor could increase employment of this group, but even in the US we observed a slowdown in the substitution of less skilled labor only.

\section{Conclusion}

It is commonplace to attribute differences in labour market performance between the US and Germany to differences in labour market flexibility. 0 ften analysts equate labour market flexibility with wage flexibility and the dispersion of pay among skill groups. But flexibility may also be interpreted in skill terms and in the extent to which less skilled workers can substitute for more skilled workers. If the labour supply is highly flexible, changes in demand may require only modest changes in relative wages. Increased demand for more skilled workers will induce firms to upgrade/substitute the less skilled for the more skilled with only modest changes in relative wages.

In this paper we have examined the relations among skill, wages and employment in Germany and the US. We have found that the German and A merican wage structures and employment structures differ substantially, but that the German and A merican skill structures also differ substantially. To some extent at least, the difference in skill structures may help us understand the differing response of the German and A merican wage structures to the economic developments of the past two decades. The German economy seems to be one with a high degree of skill flexibility where only modest wage signals are sufficient to generate quantity responses (Schettkat 1992). The US economy can reasonably be viewed as one with a low degree of skill flexibility at the bottom, where 
sizeable wage changes are needed to generate quantity responses. Taking account of skills goes someway toward explaining differences between the German and US labor markets, but it does not eliminate those differences. It does not explain why Germany reduced its wage differences while the US raised its differences, in the face of presumably similar shifts in labor demand. A nd it does not account for the lower rate of employment to population of less skilled workers compared to more skilled workers in Germany than in the US. U nder even the most extreme assumptions about how much greater flexibility could increase the employment of the less skilled German worker, we find that Germany would still have a significant employment-population gap with the US and a higher rate of unemployment. The German job problem seems to be a lack in general demand for labor rather than in skill-specific labor demand, and thus one not amenable to solution through movements along relative demand curves.

Figure 1: Standard deviations of log wages in the US and Germany

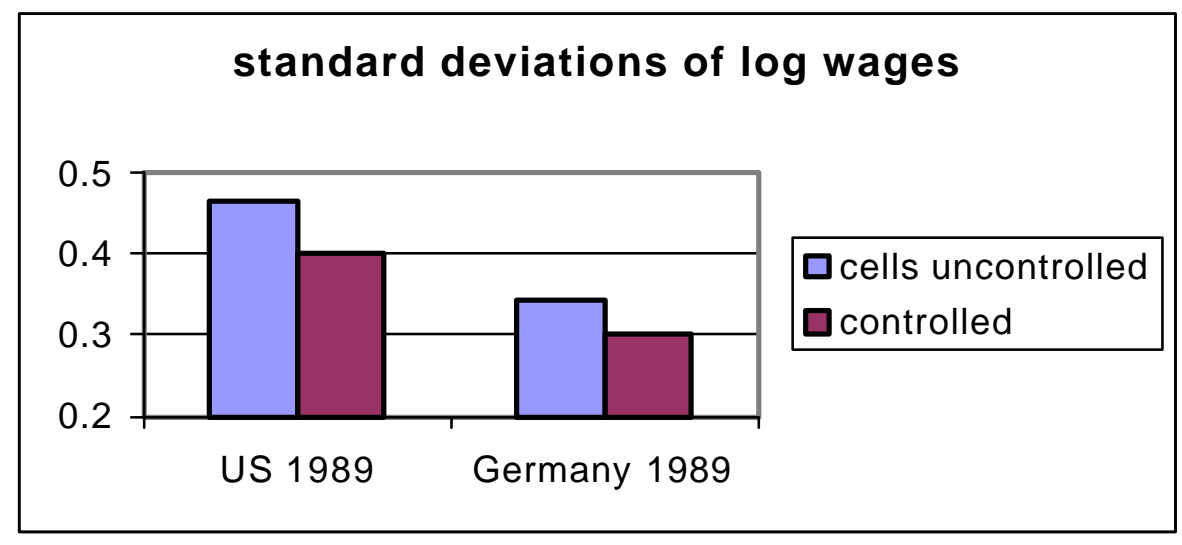

Source: computations based on CGAS.

Figure 2: Equivalent skill levels 


\begin{tabular}{|c|c|c|c|}
\hline $\begin{array}{l}\text { Skill } \\
\text { Level }\end{array}$ & US & $\begin{array}{c}\text { Years } \\
\text { of } \\
\text { schooling }\end{array}$ & Germany \\
\hline & $9^{\text {th }}$ grade & 9- & $\begin{array}{l}\text { No certificate } \\
\text { H auptschule }\end{array}$ \\
\hline & $10^{\text {th }}$ grade & 10 & Realschule \\
\hline \multirow[t]{2}{*}{ I } & $11^{\text {th }}$ grade & $\overline{11}$ & \\
\hline & $\begin{array}{l}\text { Highschool } \\
\text { graduate }\end{array}$ & 12 & $\begin{array}{l}\text { H auptschule + } \\
\text { A pprenticeship }\end{array}$ \\
\hline \multirow{3}{*}{ II } & \multirow{3}{*}{$\begin{array}{l}\begin{array}{l}\text { Some } \\
\text { college, no } \\
\text { degree }\end{array} \\
\begin{array}{l}\text { A ssociate } \\
\text { degree }\end{array}\end{array}$} & 13 & $\begin{array}{l}\text { Realschule + } \\
\text { A pprenticeship; } \\
\text { A bitur }\end{array}$ \\
\hline & & 14 & $\begin{array}{l}\text { H auptschule + } \\
\text { M eister }\end{array}$ \\
\hline & & 15 & $\begin{array}{l}\text { Realschule + } \\
\text { M eister }\end{array}$ \\
\hline \multirow[b]{2}{*}{ III } & \multirow[b]{2}{*}{$\begin{array}{l}\text { Bachelor's } \\
\text { degree }\end{array}$} & 16 & Fachhochschule \\
\hline & & 17 & $\begin{array}{l}\text { A bitur + } \\
\text { Fachhochschule }\end{array}$ \\
\hline IV & $\begin{array}{l}\text { M aster or } \\
\text { higher }\end{array}$ & $18+$ & $\begin{array}{l}\text { University } \\
\text { degrees }\end{array}$ \\
\hline
\end{tabular}

Source: 0 wn estimates. 
Table 1: Characteristics of labor market trends in the US and German economies

\begin{tabular}{|c|c|c|c|c|c|c|c|c|c|c|c|c|c|c|c|}
\hline \multirow[t]{4}{*}{ Period } & \multicolumn{2}{|c|}{$\begin{array}{l}\text { Unemployment } \\
\text { rates }\end{array}$} & \multicolumn{3}{|c|}{$\begin{array}{l}\text { Employment-population } \\
\text { ratios }\end{array}$} & \multicolumn{6}{|c|}{ Growth rates } & \multirow{3}{*}{$\begin{array}{c}\text { Profit } \\
\text { share } \\
\text { Busi- } \\
\text { ness } \\
\text { sector }\end{array}$} & \multicolumn{3}{|c|}{$\begin{array}{c}\text { W age dispersion } \\
\text { D 9/D } 1\end{array}$} \\
\hline & \multirow{2}{*}{$\begin{array}{c}\text { US } \\
\text { con- } \\
\text { cepts } \\
\text { (BLS) }\end{array}$} & \multirow{2}{*}{$\begin{array}{c}\mathrm{Na}- \\
\text { tional } \\
\text { D efin } \\
\text {-ition }\end{array}$} & \multirow[t]{2}{*}{ Total } & \multirow{2}{*}{$\begin{array}{l}\text { M anu- } \\
\text { Fac- } \\
\text { turing }\end{array}$} & \multirow{2}{*}{$\begin{array}{l}\text { Ser- } \\
\text { vices }\end{array}$} & \multirow{2}{*}{$\begin{array}{c}\text { W ork- } \\
\text { ing } \\
\text { hours }\end{array}$} & \multirow{2}{*}{$\begin{array}{l}\text { Work- } \\
\text { ing } \\
\text { volume }\end{array}$} & \multicolumn{3}{|c|}{ GDP } & \multirow[t]{2}{*}{ W ages } & & \multirow[t]{2}{*}{ M en } & \multirow[t]{2}{*}{ W omen } & \multirow[t]{2}{*}{ total } \\
\hline & & & & & & & & Total & $\begin{array}{l}\text { Per } \\
\text { capita }\end{array}$ & $\begin{array}{c}\text { Per } \\
\text { em- } \\
\text { ployed }\end{array}$ & & & & & \\
\hline & 1 & 2 & 3 & 4 & 5 & 6 & 7 & 8 & 9 & 10 & 11 & 12 & 13 & 14 & 15 \\
\hline \multicolumn{16}{|c|}{ US } \\
\hline $\begin{array}{l}1960- \\
73\end{array}$ & 4.9 & 4.9 & 63.1 & 21.3 & 36.5 & -.3 & 1.6 & 4.0 & 2.7 & 2.0 & 1.4 & 31.5 & . & . & \\
\hline $\begin{array}{l}1973- \\
79\end{array}$ & 6.5 & 6.5 & 65.2 & 20.1 & 41.3 & -.2 & 2.4 & 2.6 & 1.6 & 0.2 & 0.0 & 32.7 & 3.2 & 3.1 & \\
\hline $\begin{array}{l}1979- \\
89\end{array}$ & 7.2 & 7.2 & 68.6 & 19.2 & 46.1 & .2 & 2.1 & 2.4 & 1.5 & 0.7 & -0.9 & 33.2 & 4.0 & 3.7 & \\
\hline $\begin{array}{l}1989- \\
95\end{array}$ & 6.2 & 6.2 & 72.2 & 17.9 & 51.3 & .0 & 1.3 & 2.1 & 1.1 & 0.9 & -0.7 & 33.6 & 4.1 & 3.7 & 4.2 \\
\hline \multicolumn{16}{|c|}{ G ermany } \\
\hline $\begin{array}{l}1960- \\
73\end{array}$ & .7 & 1.0 & 69.4 & 32.6 & 28.5 & -1.1 & -.8 & 4.3 & 3.7 & 4.1 & 5.4 & 30.7 & . & . & \\
\hline $\begin{array}{l}1973- \\
79\end{array}$ & 2.7 & 3.7 & 66.5 & 29.6 & 31.4 & -1.1 & -1.2 & 2.4 & 2.5 & 2.7 & 2.5 & 29.4 & 2.4 & 2.7 & 2.7 \\
\hline $\begin{array}{l}1979- \\
89\end{array}$ & 5.6 & 7.5 & 63.8 & 26.0 & 33.6 & -.7 & -.2 & 2.0 & 1.9 & 1.5 & 1.4 & 31.4 & 2.3 & 2.4 & 2.5 \\
\hline $\begin{array}{l}1989- \\
95\end{array}$ & 5.7 & 8.1 & 65.9 & 25.5 & 37.0 & -1.1 & -.7 & 2.2 & 1.5 & 2.0 & 1.4 & 34.8 & 2.3 & 2.3 & 2.3 \\
\hline
\end{tabular}

Sources and definitions: unemployment rates form BLS international comparable data set; working hours from OECD Employment O utlook, working volume estimates; wage dispersion from OECD, Employment O utlook, 1973-79= 1979 in the US, 1983 in Germany, 1979-89 = 1989 in both countries, 1989-95 = 1993 in both countries; other data from $\mathrm{OECD}$ H istorical Statistics. 
Table 2: Relative wages and employment shares by skill levels

\begin{tabular}{lcccc} 
Skill level & \multicolumn{2}{c}{ Relative wages } & \multicolumn{2}{c}{ Employment shares } \\
U.S. & 1970 & 1989 & 1970 & 1989 \\
I & & & & \\
II & 53.1 & 49.6 & 72.6 & 55.7 \\
III & 64.3 & 61.6 & 14.1 & 21.6 \\
IV & 87.9 & 80.8 & 10.1 & 16.0 \\
G ermany & 100.0 & 100.0 & 3.2 & 6.7 \\
I & & & & \\
II & 52.1 & 56.9 & 35.8 & 18.1 \\
III & 72.5 & 73.7 & 57.7 & 69.2 \\
IV & 101.6 & 101.0 & 2.1 & 5.5 \\
& 100.0 & 100.0 & 4.4 & 7.2
\end{tabular}

Source: Computations based on CGAS 
Table 3: Rates of return in education by educational attainment, 1992 and 1994

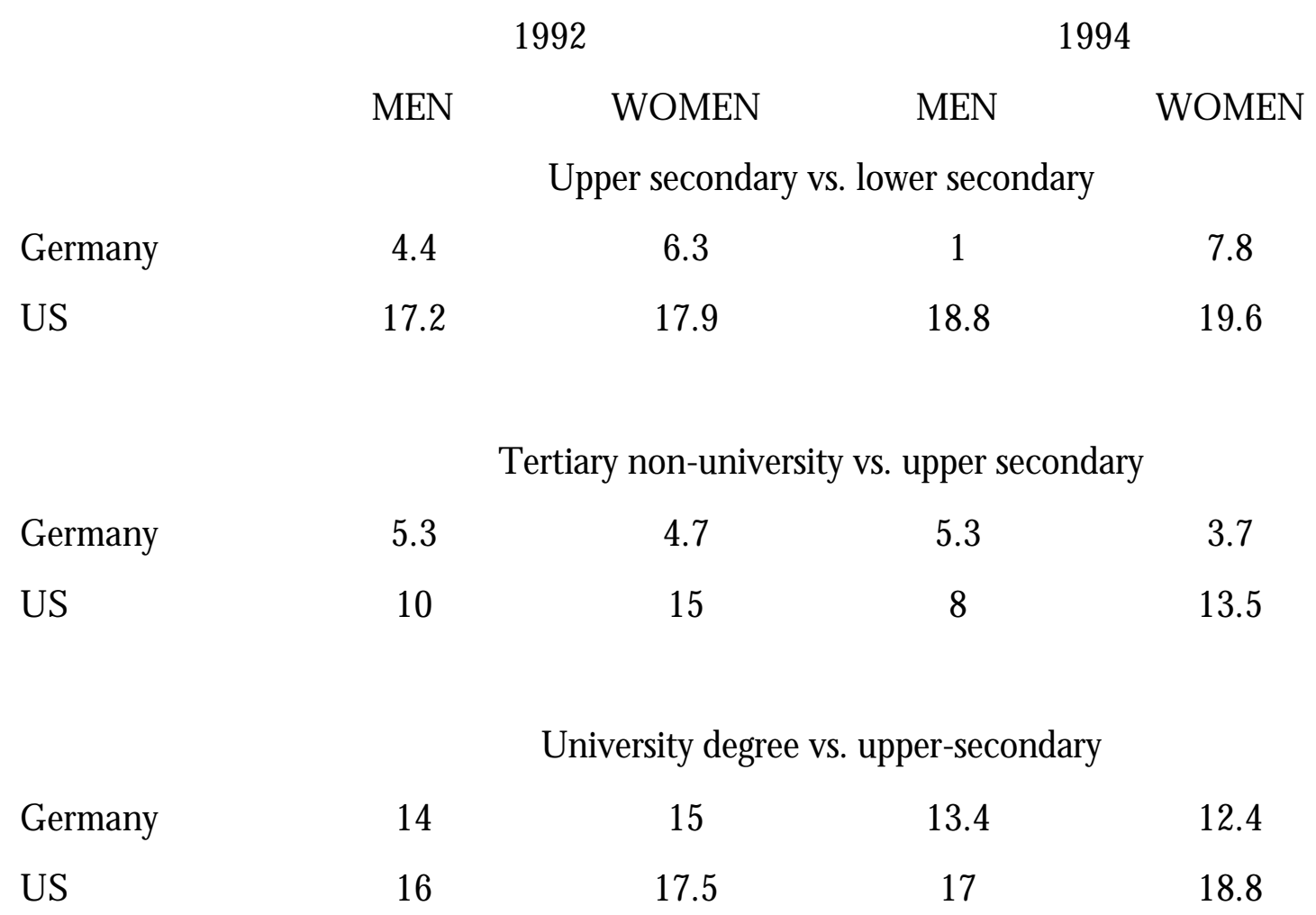

Source: International A dult Literacy Survey, OECD 1997: 159. 
T able 4: Mean literacy scores by level of educational attainment, population aged 16-65, 1994 to 1995

\begin{tabular}{|c|c|c|}
\hline $\begin{array}{c}\text { Less than upper secondary } \\
\text { education }\end{array}$ & $\begin{array}{c}\text { Completed upper secondary } \\
\text { education }\end{array}$ & Some tertiary education \\
\hline \multicolumn{3}{|c|}{ US } \\
\hline 205.1 & 269.0 & 307.6 \\
\hline \multicolumn{3}{|c|}{ Germany } \\
\hline 275.6 & 293.1 & 315.2 \\
\hline
\end{tabular}

Source: Computations based on International A dult Literacy Survey, OECD 1997: 152. 
T able 5: Percentile distribution of test scores, US and G ermany

\begin{tabular}{|l|c|c|c|c|c|}
\hline & 5 th & 25 th & M ean & 75 th & 95 th \\
\hline U.S. A verage & 133.5 & 234.6 & 272.3 & 319.4 & 370.8 \\
\hline Germany A verage & 208.2 & 255.4 & 281.4 & 316.5 & 359.3 \\
\hline
\end{tabular}

Source: Computation based on International A dult Literacy Survey, OECD 1997: 150. 
Table 6: Distribution of population in working age by literacy skills level (average of prose, document and quantitative skills, $\%$ of adult population 16-65)

\begin{tabular}{|l|c|c|c|c|}
\hline & Level 1 & Level 2 & Level 3 & Level 4/5 \\
\hline U.S. & 21.8 & 25.7 & 31.7 & 20.9 \\
\hline Germany & 10.0 & 31.2 & 40.6 & 18.6 \\
\hline
\end{tabular}

Source: Computations based on International A dult Literacy Survey, OECD 1997: 151. 
Table 7: Proportion of Population Engaging in W orkplace T asks A t Least O nce A W eek

\begin{tabular}{|l|c|c|}
\hline REA DIN G TA SKS & GERM A NY & U.S. \\
\hline Directions for instructions for medicines, recipes or other products & 31.9 & 33.8 \\
\hline Bills, invoices, spreadsheets or budget tables & 62.0 & 47.6 \\
\hline Diagrams or schematics & 51.4 & 37.6 \\
\hline M anuals or reference books, including catalogues & 60.8 & 61.6 \\
\hline Reports, articles, magazines or journals & 66.9 & 59.8 \\
\hline Letters or memos & 80.4 & 71.6 \\
\hline W RIT IN G TA SKS & & \\
\hline Letters or memos & 72.4 & 58.7 \\
\hline Forms or things such as bills, invoices or budgets & 57.8 & 51.8 \\
\hline Reports or articles & 48.3 & 44.2 \\
\hline Estimates or technical specifications & 27.0 & 29.2 \\
\hline N U M ERA CY TA SKS & 28.3 & 47.9 \\
\hline M easure or estimate the size or weight of objects & & 52.3 \\
\hline Calculate prices, costs or budgets & & \\
\hline & & \\
\hline
\end{tabular}

O ECD, Literacy, Economy and Society (Paris, 1995), table 4.1, p 89; table 4.3, p 94, table 4.5, p 97 
T able 8: U nemployment Rates, Labor Participation R ates, and Employment-Population R ates by literacy/ numeracy proficiency and by skill level, Germany and the US

\begin{tabular}{|l|c|c|c|c|c|c|}
\hline \multirow{2}{*}{ Literacy Proficiency* } & \multicolumn{5}{|c|}{ Germany } & \multicolumn{3}{c|}{ U.S. } \\
\cline { 2 - 7 } & UR & LFPR & E-Pop & UR & LFPR & E-Pop \\
\hline Level 1,2 & 16.5 & 59 & 49.3 & 7.1 & 73.0 & 67.8 \\
\hline Level 3, 4/5 & 7.2 & 72 & 66.8 & 3.4 & 84.0 & 81.1 \\
\hline Skill level** & 13.1 & 50.3 & 43.7 & 8.0 & 70.0 & 64.4 \\
\hline I & 5.2 & 70.5 & 66.8 & 3.6 & 84.0 & 81.0 \\
\hline II+ & \multicolumn{7}{|c|}{} & & & & \\
\hline
\end{tabular}

Source: International A dult Literacy Survey, OECD 1997: 163. CGA S and BLS 1997.

* population $25-65, * *$ population $15-65$. 
T able 9: Estimates of Elasticity of Substitution Between Less Skilled and M ore Skilled W orkers

U sing A Iternative C ontrasts A cross Industries, US and G ermany, 19700-1989

Comparison used

1

1970 U S relative wage and employment by industry with

1970 German relative wage and employment by industry

2

1989 U S relative wage and employment by industry with

$1989 \mathrm{G}$ erman relative wage and employment by industry

$\ln \left(\frac{E s_{i}}{E u_{i}}\right)_{G}^{t}-\ln \left(\frac{E s_{i}}{E u_{i}}\right)_{U S}^{t}=\alpha+\sigma\left[\ln \left(\frac{W s_{i}}{W u_{i}}\right)_{G}^{t}-\ln \left(\frac{W s_{i}}{W u_{i}}\right)_{U S}^{t}\right]+\varepsilon$

with:

$E s=$ employees skill groups II+, Eu = employees skill group I,

$W \mathrm{~s}=$ wages skill groups $I I+, W u=$ wages skill group $I$,

$\mathrm{G}=\mathrm{G}$ ermany (W est), $\mathrm{US}=$ U nited States,

$\mathrm{i}=$ industry subscript, $\mathrm{t}=1970,1989$.

$3 \quad$ 1970-89 Change in U S relative wage and employment, by industry

$4 \quad$ 1970-89 Change in German relative wage and employment, by industry

$\ln \left(\frac{E s_{i}}{E u_{i}}\right)_{j}^{t}-\ln \left(\frac{E s_{i}}{E u_{i}}\right)_{j}^{t-1}=\alpha+\sigma\left[\ln \left(\frac{W s_{i}}{W u_{i}}\right)_{j}^{t}-\ln \left(\frac{W s_{i}}{W u_{i}}\right)_{j}^{t-1}\right]+\varepsilon$

with:

$j=$ country subscript

5 Difference between 1970-89 Change in US relative wage and employment and 1970-89 Change in German relative wage and employment, by industry

$\left[\Delta \ln \left(\frac{E s_{i}}{E u_{i}}\right)_{G}-\Delta \ln \left(\frac{E s_{i}}{E u_{i}}\right)_{U S}\right]=\alpha+\sigma\left[\Delta \ln \left(\frac{W s_{i}}{W u_{i}}\right)_{G}-\Delta \ln \left(\frac{W s_{i}}{W u_{i}}\right)_{U S}\right]+\varepsilon$ with:

$\Delta=$ difference between 1989 and 1970,

Source: computations based on CGA S, standard errors in parenthesis. 
T able 10: M aximal Estimates of the Effect of $C$ ompressed $W$ ages at the $B$ ottom of the $G$ erman W age Distribution on U nemployment and Employment (U S concepts, 1995)

\section{Less skilled O verall}

A ctual US rates (1995)

Employment rate

Unemployment rate

A ctual German rates (US concepts, 1995)

Employment rate

Unemployment rate
72.6

Hypothetical German rates (US concepts, 1995)

I. If the employment rate of the less skilled is raised to relative U S levels but no job loss for more skilled

Employment rate

Employment growth $(1,000)$

Unemployment rate

II. If lowered relative wages of less skilled by $10 \%$ but no job loss for more skilled

Employment rate

Employment growth $(1,000)$

Unemployment rate
51.4

653.1

0.1
64.6

4.3

III. If the unemployment rate of the less skilled is lowered to relative US levels but no job loss for more skilled

Employment rate

Employment growth $(1,000)$

75.0

Unemployment rate

Source: Computations are based on CGAS and BLS figures. 


\section{Bibliography}

Beissinger, T ., M oeller, J. (1998) "W age Flexibility and Employment Performance: A M icrodata A nalysis of Different A ge-Education Groups in German Industries", mimeo U niversity of R egen sburg.

Bound, J., Johnson, G. (1992) "Changes in the Structure of W ages in the 1980's: A n Evaluation of A Iternative A merican Economic Review, 83(3), 371-392.

BLS, Bureau of Labor Statistics (1997) Comparative Civilian Labor Force Statistics, T en Countries, W ashington.

Fitzenberger, B., Franz, W . (1997) “Flexibilitaet der qualifikatorischen Lohnstruktur und Lastenverteilung der A rbeitslosigkeit: Eine oekonometrische A nalyse fuer W estdeutschland", ZEW Discussion Paper N 0. 97-32, M annheim.

Freeman, R.B., Schettkat, R. (1998) "From M CD onald's to M cKinsey: Comparing German and US Employment and W age Structures", Leverhulme II conference, Labour M arket: Stocks and Flows, 28-29 September 1998, Institute of Economics and Satistics 0 xford.

Freeman, R.B., Schettkat, R. (1999) "Low W age Services: Interpreting the US - German Difference", in G regory, M . (ed.), O xford U niversity Press, forthcoming.

Katz, L., M urphy, K. (1992) "Changes in Relative W ages 1963-1987: Supply and D emand Factors", Q uarterly Lournal of Economics, February., 35-78.

M oeller, J., (1998) Die Entwicklung der Lohnungleichheit in D eutschland, in: Statistisches Bundesamt (ed.), Einkommen und V ermoegen in Deutschland - M essung und A nalyse, Stuttgart: M etzel-Poeschel,169-193.

Nickell, S. J., Bell, B. (1996) "Changes in the Distribution of Wages and Unemployment in the OECD A merican Economic Review, 86 (5), Papers and Proceedings, 302-308.

OECD (1995) Literacy, Economy and Society, Paris.

O ECD (1997) International A dult Literacy Survey, Paris.

OECD (1998) Employment O utlook, Paris.

OECD (1998) H istorical Statistics, Diskettes, Paris.

Schettkat, R. (1992) The Labor M arket Dynamics of Economic Restructuring, N ew York: Praeger.

Siebert, H . (1997) "Labor M arket Rigidities: A t the Root of U nemployment in Europe", Lournal of Economic Perspectives 11(3): 37-54.

Steiner, V., W agner, K. (1997) "Relative Earnings and the Demand for Unskilled Labor in W est German 